\title{
ECONOMIC SITUATION OF MILK PRODUCERS AND THEIR OPINIONS REGARDING TAXATION OF THIS AGRICULTURAL ACTIVITY
}

\author{
MARIA ZUBA-CISZEWSKA \\ PIOTR POMORSKI
}

\begin{abstract}
For many years, Poland has been looking for a new taxation structure for income from agricultural activities in place of the agricultural tax which is still a basic burden for Polish farms. The study presents the results of the tax awareness analysis carried out in the selected group of farmers i.e. those involved in the cow's milk production (32), so as to conclude, on this basis, on the assessment of tax fiscalism among this professional group. Tax burdens, both within the entire taxation system, as well as within new tax solutions, are perceived and expressed in a subjective way. The overall assessment of the tax system in terms of social expectations and reactions is dependent on, inter alia, the level of education of taxpayers, legal awareness, prevailing attitudes towards taxation. The results of the presented studies have shown a low level of tax awareness among farmers. The primary source of knowledge on taxes, including tax reliefs, are other farmers and information from tax authorities. The fiscal burden of taxes paid for the analysed group of farmers is not large. Few of them consider the following taxes as at least significant fiscal burden: agricultural tax (21.9\%), real property tax (21.9\%) or forestry tax (3.1\%). According to the surveyed, the reasons for non-payment of taxes are mainly economic. The respondents consider the agricultural tax structure as appropriate. Most of the surveyed (56.3\%) hold a negative attitude towards introducing the income tax on farmers and their agricultural activity. If it was to be introduced, it should be accompa-
\end{abstract}

Dr Maria Zuba-Ciszewska, The John Paul Il Catholic University of Lublin, Faculty of Social Sciences, Institute of Economics and Finance; Al. Racławickie 14, 20-950 Lublin (maria.zuba@kul.pl). ORCID iD: 0000-0002-5543-1620.

Dr Piotr Pomorski, The John Paul II Catholic University of Lublin, Faculty of Law, Canon Law and Administration, Institute of Legal Sciences; Al. Racławickie 14, 20-950 Lublin (piotrpom@kul.pl). ORCID iD: 0000-0001-7962-936X. 
nied by tax reliefs, associated mainly with crisis situations, as well as investment allowances and reliefs dependent on the farm size. Despite modernisation or acquisition of new land incorporated into their farms, some farmers have not used an investment allowance. The reason for this state of affairs was, inter alia, the lack of knowledge on the suitable legislation. Farmers have a poor knowledge on the methods of paying tax liabilities and mostly do not use them. Almost all (93.8\%) farmers know the possibility of recovering some funds spent on diesel fuel used for the agricultural production on a basis of invoices presented. Few $(6.3 \%)$ believe that the current limit of excise tax refund is satisfactory. More than $31 \%$ of the surveyed use professional assistance (mainly accounting offices) as regards implementing obligations related to VAT settlement. The selection of the settlement method is conditioned economically.

Keywords: tax fiscalism, tax awareness, agricultural tax, milk producer.

JEL codes: H2, H31, Q12, Q14.

\section{The phenomenon of fiscalism in the context of agricultural taxation}

Although the issue of fiscalism is the subject of many theoretical analyses and empirical experience, it has not been given a uniform definition. The interdisciplinary approach to the issue of fiscalism combines at least three crucial issues: problem of tax authority, analysis of social expectations and responses in the context of taxation and assessment of political and economic conditions. From the public perspective, the essence of fiscalism consisting in shaping the scale and structure of tax burdens is the domain of the state, as other entities do not have sovereignty over financial, tax and customs issues (Owsiak, 2002). The doctrine stipulates that any tax - including the agricultural tax - is a political problem of the authority, and the decision to distribute tax burdens is in the hands of the current political majority in the resolution-passing bodies of the state and local government (Gomułowicz and Małecki, 2006). Fiscalism is one of the most important elements determining the proper functioning of entrepreneurs and other entities (including farmers), especially in terms of their independence and self-financing. Assuming that the tax system is a derivative of political activities, it should be created and modified so as to implement both fiscal and non-fiscal tasks in the optimal manner. Taking into account the fiscal criteria, the tax system is a complex structure built to meet the demand of public authorities for funds taken from taxpayers' pockets (Gilowska, 2003).

From taxpayers' perspective, all tax burdens are experienced and expressed in a subjective manner. When selecting proper tax instruments, the authority in the "tax state" must be very sensitive to all signals from taxpayers related to responses to taxation. Therefore, the extraction of the full economic potential from taxes, while maintaining tax justice, seem to be the ultimate objectives of the tax policy and the tax system. Taxation ideas and strategies are an expression of ever-changing social and economic conditions, a different meaning given to values and legal 
norms in the light of a constant conflict between the budget needs and economic interests of taxpayers. The creation of tax burdens must be based on a well-thought operation of the power apparatus geared towards achieving the objectives which are identified ex ante and agreed by way of compromise, rather in a long than short term. The literature points out that the tax burden should be determined by the structure of the economy resulting from the integrated budget functions and technological conditions that determine the level of labour productivity and employment (Żyżyński, 2009).

Fiscalism is assessed on certain scales and the tax is considered excessive if, in order to pay it, the taxpayer must limit expenses on developing agricultural or non-agricultural activity, or when he is not longer interested in increasing income from that activity or from own labour (Pietrewicz, 1993). Conversely, we can speak about the reasonable level of fiscalism when the scale of public authorities' interference in income of individual or corporate entities allows to meet the needs of public authorities in terms of income, allows farmers and entrepreneurs to function and develop and also allows households to meet their consumer needs at the best level, thus creating conditions for saving money (Dynus, 2007). It should also be remembered that the degree of fiscalism is determined primarily by the conditions and barriers of the expenditure policy. Therefore, excessive fiscalism negatively affects not only the social reception of taxes, manifested by an increased scale of evasions or tax savings, but is also a sort of trap for the legislator, who will now find it more difficult to withdraw from previously promised and legally adopted public expenses (Grądalski, 2004).

It should also be stressed that the existing legal regulation, legal awareness, ethical assessment, the level of education of taxpayers should be taken into account when selecting the measures and objectives of tax policy, also that addressed to agriculture. An important objective of this policy is to properly balance the public and private interests so as to ensure harmony between the need to provide public funds for the efficient functioning of state institutions while minimising the nuisance of tax burdens (Pietrewicz, 1993). It also seems that if taxpayers approve not only the level of burden, but also the way the authorities redistribute taxes paid, then the pressure of tax fiscalism will not be so clearly experienced. In this sense, the authorities should inform and educate taxpayers about what tax revenues are spent on. Providing taxpayers with at least minimum control over tax redistribution is a distinguishing feature of the modern, democratic tax system (Listokin and Schizer, 2013). The effectiveness of the tax system is determined not only by the amount of tax revenues collected in the budget, but also by what attitudes towards taxation are dominant, whether the severity of tax sanctions or inevitability of tax controls will be the factors, at any given time and place, triggering a better motivation to pay taxes. Decentralisation of public finance, support for private initiatives, stimulation of efficiency of management are factors which do not correspond to the excessively fiscal tax system. The taxation bases and rates should be constructed in such a way as to increase social prosperity. The higher are material inequalities in the society, the lower is the level of this prosperity - as well as the level of tax justice (Heady, 
2007). This is not just about material priorities; the feeling of prosperity is affected by the conditions of living, health and its protection, environmental cleanliness, guarantee of employment according to qualifications and for a decent remuneration, finally - real opportunities for professional advancement (Winiarski, 2000).

Agriculture is a specific sector of the economy and its main objective is to provide food security. Agricultural activity is characterised by the seasonality of production, limited mobility of production factors (especially land), short-term market variability and the specificity of agricultural turnover. It is encumbered with a high level of risk (Adamowicz, 2019). Thus, aspects other than purely fiscal ones are taken into account when taxing agricultural activity. The factors such as the agrarian structure, production structure or structure of agricultural services have a major impact when selecting the taxation method for agricultural activity. The attitude of a given state towards agriculture (in a form of support or neutrality) affects the selection of the relevant tax model. In the case of European countries, three groups of countries can be identified in this regard (Burzec, 2018; Gruziel and Raczkowska, 2018). Taxation of agriculture in Poland has changed according to historical conditions (Podstawka, 1995). Currently, taxation of Polish farms includes taxes of income, property or revenue character. Farmers also pay certain levies (Kulawik, Lelong, Pawłowska-Tyszko and Soliwoda, 2013). However, property taxes remain the most typical fiscal burdens on agriculture; although they do not play a leading role in the general tax system, they are an important source of local government's income in most countries (Presbitero, Sacchi and Zazarro, 2014).

The objective of the study is to assess tax awareness of the selected group of farmers, i.e. those involved in the cow's milk production. The task is to answer important questions, i.e. what is the state of knowledge of the respondents regarding taxes and the need to incur tax burdens, what is their knowledge on various settlement options, what benefits for different types of farms are brought by various solutions and proposed tax reliefs, whether tax awareness is related to the economic situation of the farm. The results presented are part of the studies on assessing current tax solutions in agriculture and a proposal of their reform. ${ }^{1}$

\section{Economic situation of milk producers}

The study sample, selected purposively, consisted of 32 farms specialised in rearing dairy cows from the following voivodeships: Podlaskie (19), Łódzkie (5), Lubelskie (4), Świętokrzyskie (2), Mazowieckie (2). Among 120 persons from the analysed farms, young persons (up to 18 years) represented $12.5 \%$, while retirees accounted for $16.7 \%$, of which the number of female retirees was twice higher than the number of male retirees. The largest group (43.3\%) were persons aged 35-60 (65). Among adults, males were dominant (53.3\%), and half of them were aged 35-65. On 59\% of farms, their managers (one or both) had agricultural education, including higher education. Over $1 / 3$ of female farmers and only 4 male

\footnotetext{
${ }^{1}$ These studies were conducted in 2017 as part of the project "New model of taxation of agriculture in Poland", NCN, DEC-2013/09/B/455/04503.
} 
farmers had higher non-agricultural education. On 25 farms, there were young persons below 35 , but only on 8 of them it was declared that any of children would take over the farm and continue the agricultural production. On half of farms, there were no retirees. Most farms were small (40.6\% up to 10 ha of UAA) and medium small (34.4\%, 10-20 ha). Only six farms had 20-30 ha of own UAA and two were large farms (from 30 to $50 \mathrm{ha}$ ). On 22 farms, UAA was additionally leased, on 15 of them this area did not exceed 10 ha and only two used more than 30 ha. On half of farms, PG accounted for more than 50\% of UAA, in the case of leased PG this percentage was obtained by only 6 farms. The average value of production assets in a form of buildings and structures was PLN 314.5 thousand, of machinery and vehicles - PLN 286.6 thousand, other elements, including the production herd - PLN 100 thousand. However, for half of farms those values were lower (by 25, 30 and 10\%).

Most analysed farms (24) are planning to continue their specialisation in the milk production. But only 10 of them consider their farm as developmental and 12 - as stabilised, in two cases the opinion was "non-developmental farm". According to plans for a few next years, two farms will be taken over by younger successors, one will reduce its activity due to the lack of successors and the unprofitability of production, one will be sold. In relation to 11 farms which are considered as developmental (7) or stabilised (4), it is planned to expand them, mainly for economic reasons (32\% of answers) such as the increase in income, in the profitability of production, in the production scale and investment activity, including investments in land. As many as 17 farms are to be left unchanged in the nearest years. The reasons for this plan are mostly negative. The highest number of answers $(38 \%)$ concerned the low profitability of milk production, including low and variable prices for milk, unstable situation and related uncertain future and the lack of opportunities to develop the farm. Threats regarding the labour resource (age, lack of workers or successors, lack of time, disease) accounted for $26 \%$ of all answers and those related to capital (no funds, necessity to repay already contracted credits, fear of contracting a credit) $-14 \%$. The positive reasons for the lack of change on the farms, such as sufficient income achieved, land resource owned or the number of cows and related suitable production scale accounted for only $14 \%$ of answers.

Nearly half of farms (15) in the nearest years are planning to invest in purchasing animals, equipment and machinery (8), construction work (6), and even in additional production (northern highbush blueberry). For 14 farms, savings are the main source of financing investments. For other (18) entities surveyed, these are credits granted mainly by a cooperative bank (12). The dominance of cooperative banks in granting investment credits to farmers results, inter alia, from the implementation of the "relationship banking" model, based on close contacts with customers and processing the possibly extensive set of information about them (Kulawik and Ziółkowska, 2006), which is important when selecting a bank by farmers. These banks reduce credit constraints resulting from information asymmetry (Kata, 2010). Farmers have no problem either with repaying their liabilities $(93.8 \%)$ or access to credits $(100 \%)$. 
The average value of the commodity production obtained by farms was PLN 198.2 thousand, whereby for half of farms this production was lower by $20 \%$. Income achieved from the sale of agricultural production amounted to, on average, PLN 95 thousand but for half of farms it was significantly lower (PLN 62.5 thousand). On average, subsidies obtained by the farm accounted for, on average, almost $48 \%$ of income from production, and reached $32 \%$ in every other farm. That is why $65 \%$ of the surveyed assessed the positive impact of the accession to the EU on the economic situation of farms, thus confirming that the CAP had a significant impact on the state of agriculture in the country, including the situation of farms (Krzyżanowski, 2015).

For only half of farms (17), income achieved would allow them to develop in the future, and for $3 / 4$ it is sufficient to avoid using external sources. For 22 farms, the level of income is sufficient to cover consumer needs to a degree which is at least fairly good, and for 59\% of them income also allows to save money. For 10 farms whose income satisfies the consumption only sufficiently, only $20 \%$ are able to save money.

\section{Tax awareness of milk producers surveyed}

Other farmers are a primary source of knowledge on taxes, including tax reliefs, for farmers, as indicated by $3 / 4$ of them. For $2 / 3$, such sources are information from tax authorities and for $37.5 \%$ - media. Only $15.6 \%$ of farmers, as a source of information, indicated training courses organised for farmers. Tax awareness of the farmers surveyed is quite low. Although $84 \%$ of them declared they knew tax reliefs, usually only one type of relief was mentioned, in addition not always the one being applicable. The most popular tax relief is the construction/investment tax relief, which was indicated by half of the respondents as well as the land purchase tax relief ( 8 answers) and the natural disaster tax relief ( 6 answers). More than half of the surveyed $(53 \%)$ used tax reliefs in the past, others did not use them due to the lack of knowledge on the existence of tax reliefs, necessity or non-compliance with the required criteria for granting tax reliefs.

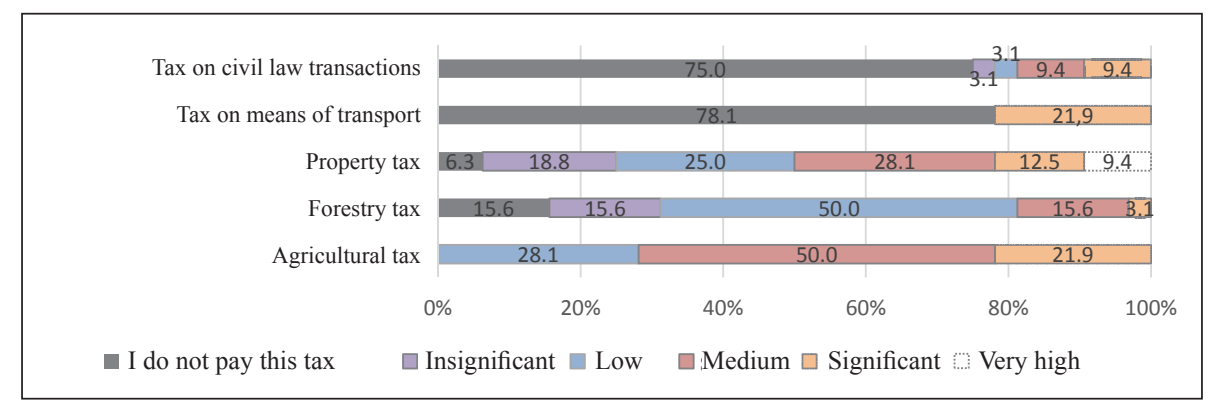

Fig. 1. Tax burdens on farmers.

Source: own study. 
The agricultural tax is not a heavy burden on farmers (Fig. 1). The majority of farmers $(78.1 \%)$ stated that this tax is a fiscal burden on them to a low or medium extent. For almost $72 \%$ of the surveyed, the property tax is a burden on them to a medium extent at the most. The forestry tax is the least fiscally burdensome on farmers as only one in 27 persons paying indicated it as a significant burden. The tax on means of transport and the tax on civil law transactions is paid by few farmers ( 7 and 8 farmers, respectively), who feel their burden as significant at the most. None of the surveyed pays the income tax.

In the opinion of the respondents, the major reasons for which farmers do not pay taxes are economic: lack of funds, poor financial situation (12 answers), low income, low profitability of production (10). The individual persons indicated the excessively high level of taxes (3 times), natural disasters (1), fortuitous situations, forgetting, mess of documents (2). Therefore, reduced tax rates (53.1\% of answers) and simplified tax settlements $(28.6 \%)$ would contribute most to improving the collectability of taxes. More frequent tax controls or increased penalties for non-payment of taxes would be an effective tool to a lesser extent (16.4\%).

The majority of the respondents $(56.3 \%)$ have a negative attitude towards the introduction of income tax on farmers and their agricultural activity, and only $15.6 \%$ have a positive attitude. The rest $(28.1 \%)$ have no opinion on this matter. For most farmers, the most important tax reliefs accompanying the income tax introduced in the future (Fig. 2) should be tax reliefs granted in crisis situations, e.g. in the case of disasters or a fall in prices of agricultural crops (for $71.9 \%$ of persons). This is due to the risk which accompanies the agricultural production and manifests itself, inter alia, in the growing climate variability in recent years, the effects of which are experienced throughout Poland. However, still few farmers conclude a disaster insurance contract due to, inter alia, significant costs of taking out an insurance policy (Czekaj, 2016). Farmers also expect support in the event of a fall in prices in the market. The price risk in agriculture, due to time shifts between decision-making and the effect obtained, is large. The price risk is created by risk exposure, i.e. exposure to the undesirable consequences of uncertain events, and price variability (Figiel, Hamulczuk and Klimkowski, 2012). Price variability creates uncertainty regarding the implementation of the target (income) function by farmers. Therefore, even high variability will not necessarily significantly reduce the probability of implementing the price function (price risk) if there are tools that mitigate negative effects, e.g. state programmes (Hamulczuk, 2014), including tax reliefs.

Further positions in terms of relevance were occupied by tax reliefs related to investments in the farm $(62.5 \%)$, tax reliefs depending on the farm size $(56.3 \%)$, tax reliefs for young farmers $(40.6 \%)$. Less important would be those related to the type of crops or breeding (34.4\%), employment of a family or workers on the farm $(31.3 \%)$ or organic production $(9.4 \%)$. 


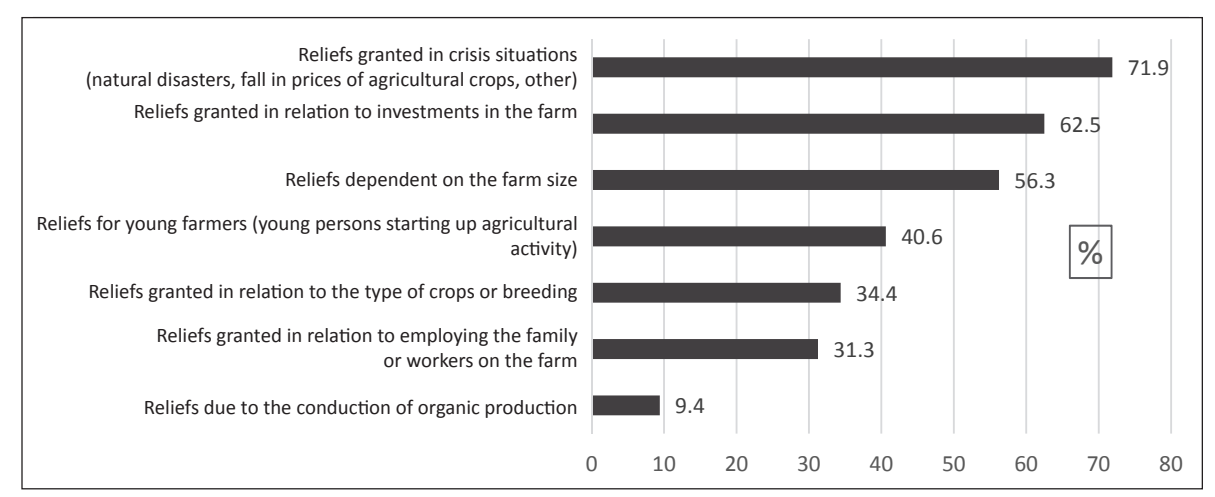

Fig. 2. Tax reliefs in income tax.

Source: own study.

Only every fourth farmer surveyed said that farmers are able to manage their tax matters on their own. This attitude results from the ignorance of the legislation. Almost 2/3 of the surveyed would like to have their tax calculated and the tax decision delivered by the tax authority. Lump-sum payment in advance as a form of the income tax on farmers would be chosen by $22 \%$ of them, and every eighth farmer would like to calculate and pay taxes on their own.

Since Poland's accession to the EU, the area of the farm has remained unchanged on half of farms. For 3 farms, this area decreased and, in the case of 13, it increased as a result of purchasing land (11) or lease (2). The source of funds for purchasing land was a credit or loan (6 answers), income achieved (5), savings (4) and subsidies (1). Land was most often purchased from a neighbour (10 times), and also from the family (2). No one indicated the Agricultural Property Agency. Some persons purchasing land $(42.8 \%)$ did not use an exemption from the agricultural tax, mainly as a result of ignorance of that exemption. For three farms whose area decreased, this was due to a lack of persons to work on the farm resulting from the fact that the children had left for the city, land had been sold for fortuitous reasons, or for any other reason. On the other hand, half of farms have not changed their area. The farmers from those farms mentioned the following reasons: too high prices of agricultural land $(62.5 \%)$, no profitability of increasing the agricultural production (50\%), lack of own resources $(50 \%)$, lack of available agricultural land in the area (37.5\%), as well as lack of persons to work on the farm $(31.3 \%)$. To a lesser extent, the reasons were the reluctance to contract a credit/loan for this purpose (12.5\%) and the lack of creditworthiness $(6.3 \%)$. The main incentive to expand the farm for all those who did not change it (Fig. 3) would be higher prices of products, i.e. milk $(100 \%)$. This opinion confirms the studies on the important relation between the variability of prices of milk and the farm investment opportunities. Price fluctuations are particularly dangerous for implementing investments on smaller farms (Kołoszycz, 2017). For the majority of farmers surveyed in this group, of importance are also factors such as tax 
exemptions or reliefs $(81.3 \%)$, subsidies $(81.3 \%)$, favourable economic situation in the agricultural market (75\%). Less important (according to $12.5 \%$ of the surveyed) would be preferential credits or imitations of others in the neighbourhood or in the family.

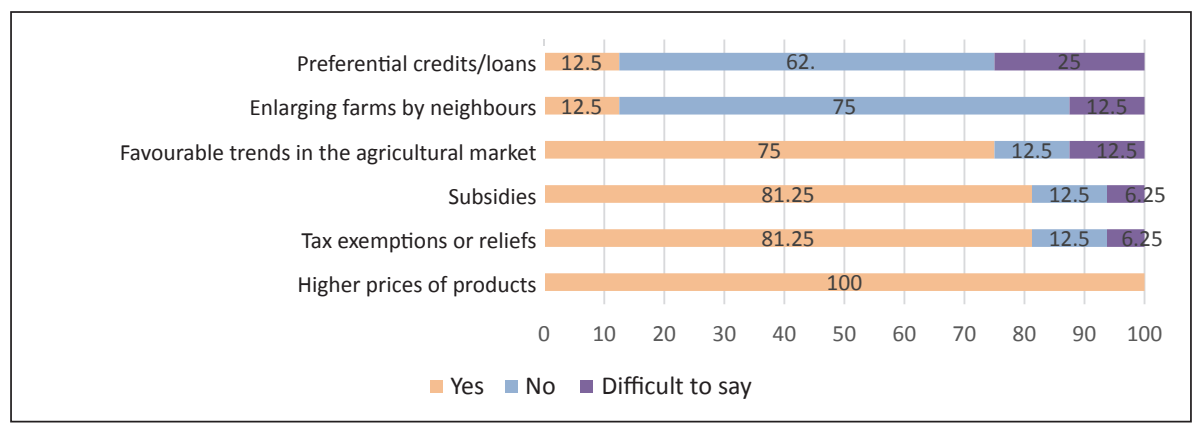

Fig. 3. Determinants of expanding the farm (\%).

Source: own study.

After 1 May 2004, half of farms were modernised. What was used for this purpose, were mainly savings $(75 \%)$ and income achieved $(62.5 \%)$, to a lesser extent - a credit or loan (43.8\%) or EU funds (43.8\%). The modernisation mainly included the purchase of agricultural machinery and equipment (68.8\%). Another type of modernisation was the expansion of livestock buildings $(56.3 \%)$, their renovation $(37.5 \%)$ or construction $(37.5 \%)$, as well as the renovation of environmental facilities $(18.8 \%)$, their expansion $(6.3 \%)$ or construction $(6.3 \%)$. Therefore, the type of modernisation of dairy farms, started in 1995 by preferential credits for the restructuring of the whole dairy industry from the state budget, which covered 3/4 of the interest rate, has remained. In the period of 1995-2005, the value of preferential credits granted to farmers in this industry amounted to PLN 1,069.5 million. In addition, from the SAPARD pre-accession programme farmers received PLN 77.6 million for the modernisation of farms, of which they spent $82 \%$ on the purchase of machinery and equipment for production, and $10 \%$ for the purchase of dairy cows of more productive breeds. These measures resulted in a very quick improvement in the quality of raw materials (Seremak-Bulge (ed.), 2005). Only 10 farmers from 16 farms being modernised used the investment allowance in agricultural tax. The others did not use it as they were not entitled to receive this allowance ( 4 answers), it entailed too many formalities (3), they had no knowledge on it (3) or the rules were illegible for them (2), or because the source of investment was EU funds or other grants (3). All farmers not using the allowance stated that it should be extended. The allowance should also be granted for the modernisation or construction of buildings other than those used for the rearing, breeding and keeping of livestock, the allowance should include the acquisition of necessary agricultural machinery within the farm, the allowance should cover the costs incurred when starting to conduct organic farming, 
more than $25 \%$ of the investment costs should be deducted, when the farmer starts conducting the livestock production the allowance should include the primary acquisition of an animal herd.

In the case of another exemption of UAA, where the agricultural production has been ceased (i.e. set-aside relief), from the agricultural tax, only on three farms land was set aside at least once after 1 May 2004. Setting land aside was due to the lack of persons to work, temporary difficulties (economic, personal), receiving an EU subsidy. Two farms set aside between $20 \%$ and $30 \%$ of the farm's area, and one farm - more than 50\%. Farmers did not use the exemption from the agricultural tax for the land on which the agricultural production has been ceased and are unlikely to use it in the near future.

As regards the opinion on the conditions of exempting set-aside land from the agricultural tax, $75 \%$ of the surveyed (of 32) believe that the exemption should cover, just like before, less than $20 \%$ of the farm's utilised agricultural area. Some respondents would increase this limit to $30 \%$ (6 persons) or up to $50 \%$ (two persons). The majority of the respondents $(81.3 \%)$ would not change the number of ha (10 ha) of set-aside land allowing to use the relief. Few would like to have it doubled (9.4\%), tripled (3.1\%) quadrupled (6.3\%). According to $34.4 \%$ of the surveyed, the period of exempting set-aside land from the agricultural tax should remain unchanged. The majority would like to shorten it (to 1 year $-43.8 \%$ or 2 years $-9.4 \%)$. Few would like to extend it from the current 3 to 4 years $(12.5 \%)$.

The majority of the respondents believe that the agricultural tax should be paid on the area expressed in conversion hectares $(81.3 \%)$. For $84.4 \%$ of farmers, the basis for the agricultural tax should not be the area expressed in physical hectares. Even more respondents $(90.6 \%)$ are negative towards the market value of agricultural land as the base for the agricultural tax. The most criticised is the rent value of land (from the amount that can be obtained for land lease) as a taxation base $(96.9 \%)$.

None of the farmers surveyed has ever been summoned by the tax authority to provide explanations related to the tax being paid. Tax control has been initiated in relation to one farmer. Its initiation resulted from the fact that the taxpayer had received from the tax authority a notice on the initiation of control and the order to prepare for it. This control included the inspection of land and buildings belonging to the taxpayer.

The majority of the farmers surveyed $(68.8 \%)$ have never submitted a request to initiate a tax procedure for granting a tax relief. Among those who submitted the request, most cases (7) concerned the tax relief in a form of deferring payment of the tax or tax arrears. Few requests concerned the tax relief in a form of arranging instalments for payment of the tax or tax arrears (3) or the tax relief in a form of annulment of tax arrears (1).

The farmers have a poor knowledge on the methods to pay tax liabilities such as paying overpayment towards tax arrears or current liabilities $(28.1 \%)$, offsetting mutual debts with a local government unit (18.8\%), transfer the property 
ownership or property rights to a local government unit (21.9\%). Only two farmers used those methods.

Almost all (93.8\%) farmers have knowledge of the possibility of recovering some funds spent on diesel oil used for the agricultural production based on invoices presented. Few $(6.3 \%)$ believe that the current limit of excise tax refund is satisfactory.

Only one farmer has ever used individual tax law interpretations. Similarly, only one person has ever entered into a dispute with tax authorities regarding VAT taxation of agricultural activity. More than $31 \%$ of the respondents use professional assistance in meeting VAT settlement obligations. Among these 10 people, the majority use services of an accounting office, and only one person employs an accountant. It is, therefore, confirmed that Poland belongs to the EU countries where the level of using services by farms is low (Kołodziejczak, 2016).

Among the surveyed, 19 farmers pay the lump-sum tax, 11 settle their tax in line with general principles of taxation (as an active taxpayer settling and paying VAT). One farmer declared being exempt from VAT due to the amount of turnover (exemption for so-called small entrepreneurs) and justified his choice of taxation by failing to meet the conditions for using the status of a lump-sum taxpayer. No response was received from one farm in this regard.

All farmers who settle their tax in line with general principles of taxation are not "lump-sum taxpayers" because VAT refund in line with general principles of taxation is more beneficial to them. Most of them in recent years have modernised their farm by constructing/expanding buildings or by purchasing new machinery and equipment. And at the time of purchasing agricultural machinery and construction materials, farmers benefit from VAT refunds (Nachtman and Cholewa, 2016). On the other hand, the reasons for non-selection of this type of taxation are not: the need to keep accounts pursuant to separate rules, delivering agricultural products other than those derived from own agricultural activity, conducting non-agricultural activity in addition to agricultural activity, or the fact that customers of agricultural products derived from own agricultural activity are not active VAT taxpayers (taxpayers settling VAT). Some of these 11 farmers (9 persons) are the purchasers of agricultural products or products provided by lump-sum farmers, or services provided by lump-sum farmers, and do not find formal obligations (issuing RR invoices, making bank transfers, etc.) related to transactions with lumpsum farmers excessively burdensome.

Lump-sum farmers use an exemption for lump-sum farmers, as VAT refund in this form is more beneficial to them $(73.7 \%)$, VAT settlement in line with general principles of taxation is too complicated and entails too many formal legal obligations, such as, e.g. keeping records, issuing invoices $(68.4 \%)$, it is beneficial that they do not have to keep records, issue invoices and submit tax returns (78.9\%). All lump-sum taxpayers do not conduct any economic activity in addition to agricultural activity as part of which they are lump-sum taxpayers. Exporters (14 farmers) of agricultural products derived from own production do not settle VAT separately 
for this purpose, inter alia, due to the nuisance resulting from the related recordkeeping. The majority of lump-sum taxpayers $(89.5 \%)$ believe that the applicable VAT settlement mechanism for lump-sum farmers is beneficial to them. No lumpsum taxpayer has happened to receive lump-sum VAT refund from the purchaser of agricultural products or from service providers.

\section{Discussion and summary}

The basic burden, i.e. the agricultural tax, in its normative shape, demonstrates the elements of the property and income tax (Borszowski, 2013). Its essence consists in burdening the assets, i.e. conversion hectares forming the farm, with the tax obligation. The amount of this levy depends to a large extent on the conditions of conducting agricultural activity, such as economic and natural conditions, while ignoring, for example, the type and level of efficiency of management or connection with farm income (Kisiel and Idźkowska, 2014). The advantages of this tax (low transaction costs, simple calculation, low burden on farmers' income) are less likely to be seen than its disadvantages. Despite the assumptions in the construction, the tax does not take into account the impact of differential rent I on the economic results of farms (Podstawka, 2005). Its form does not encourage farm owners to intensify the production, delays the process of enlarging farms, and thus does not implement a stimulating function, while small proceeds from this tax indicate the low efficiency of this tax (Wasilewski and Ganc, 2012; Forfa, 2011), and the role of land, as the major factor shaping agricultural income, is decreasing (Podstawka, 2000). Social disapproval is expressed against farmers exempt from paying income tax. It refers particularly to large, economically strong farms for which the amount of tax is disproportionate to income achieved (Cholewa and Nachtman, 2014). Existing plans to introduce income tax in relation to personal income achieved from agricultural activity have failed (Chlebicka and Lewandowski-Lepak, 2012).

Therefore, important are scientific studies on the assessment of such a solution by farmers (Kubot and Czubak, 2016; Pawlak, Paszko and Karwacki, 2017) as well as the attitudes of farmers towards the entire taxation system of agricultural activity, especially taking into account the economic situation of farms (Peciakowski and Gizicka, 2018).

Despite the reduction in the study, which is a small study sample, it appears that the findings of the study may be helpful in the study challenge of developing an new structure of taxation of farmers in Poland. The agricultural tax system which has existed for more than 30 years and whose dimension corresponds to a small extent to the profitability of farms and collection does not bring any significant fiscal effets to budgets of local government units is a simple structure (Felis, 2015) that does not go with the requirements of the modern tax system, however, as shown by the studies, it is deeply rooted in the minds of farmers. Some authors believe that such marginal tax burdens on farmers are a hidden form of co-financing for this sphere of economy (Soliwoda and Pawłowska-Tyszko, 2014). It seems that the 
greatest challenge in reforming the agricultural sector is to overcome the misgivings of taxpayers as regards the diversification of tax burdens, which is being demanded to be led to covering income from agricultural activity with the general or lump-sum income tax, while excluding from its structure those property elements related to the area of the farm and other real properties used for the agricultural production. 


\section{References}

Adamowicz, M. (2019). Wspólna polityka rolna Unii Europejskiej jako forma wsparcia finansowego rolnictwa i obszarów wiejskich. In: S. Juszczyk (ed.), Finanse agrobiznesu (pp. 37-103). Warszawa: PWN.

Borszowski, P. (2013). Podatek rolny. In: R. Mastalski, E. Fojcik-Mastalska (ed.), Prawo finansowe (pp. 348-351). Warszawa: Wolters Kluwer.

Burzec, M. (2018). Opodatkowanie działalności rolniczej w wybranych państwach europejskich. In: P. Smoleń (red.), Opodatkowanie rolnictwa w Polsce. Weryfikacja założeń. Perspektywa zmian (pp. 65-127). Warszawa: C.H.Beck.

Cholewa, I., Nachtman, G. (2014). Analiza przewidywanych skutków wprowadzenia reformy podatkowej w polskim rolnictwie na tle rozwiązań niemieckich. Zagadnienia Ekonomiki Rolnej, nr 2(339), s. 104-126.

Chlebicka, A., Lewandowski-Lepak, R. (2012). Objęcie dochodów z działalności rolniczej podatkiem dochodowym od osób fizycznych w Polsce. Roczniki Naukowe SERiA, Vol. XIV, Issue 3, pp. 38-41.

Czekaj, Z. (2016). Zagrożenia klimatyczne w rolnictwie a ubezpieczenia upraw. Wiadomości Ubezpieczeniowe, No. 2, pp. 145-157.

Dynus, M. (2007). Polityka fiskalna. Toruń: TNOiK.

Figiel, S., Hamulczuk, M., Klimkowski, C. (2012). Metodyczne aspekty analizy zmienności cen oraz pomiaru ryzyka cenowego na towarowych rynkach rolnych. Komunikaty, Raporty, Ekspertyzy, Vol. 559. Warszawa: IERiGŻ-PIB.

Felis, P. (2015). Agricultural Tax Efficiency in Poland, Management Theory and Studies for Rural Business and Infrastructure Development, Vol. 37(1), pp. 38-47. DOI: 10.15544/MTS.2015.04.

Forfa, M. (2011). Podatek rolny a rozwój gospodarstw rolnych. Zeszyty Naukowe SGGW-Ekonomika i Organizacja Gospodarki Żywnościowej, No. 89, pp. 75-82.

Gilowska, Z. (2003). Główne słabości polskiego systemu podatkowego. In: A. Pomorska (ed.), Kierunki reformy polskiego systemu podatkowego (pp. 37-46). Lublin: Wydawnictwo UMCS.

Głuchowski, J. (2002). Powody ustanawiania ulg i zwolnień podatkowych. In: J. Głuchowski, D. Handor, J. Patyk, J. Szymańska (ed.), Formy zmniejszania wysokości podatków w Polsce (pp. 19-24). Warszawa: PWN.

Gomułowicz, A., Małecki, J. (2006). Podatki i prawo podatkowe. Warszawa: LexisNexis.

Grądalski, F. (2004). Wstęp do teorii opodatkowania. Warszawa: SGH OFICYNA.

Gruziel, K., Raczkowska, M. (2018). The Taxation of Agriculture in the European Union Countries. Problems of World Agriculture, No. 18(4), pp. 162-174. DOI: 10.22630/PRS.2018.18.4.107.

Hamulczuk, M. (2014). Ryzyko cenowe a zmienność cen i relacji cenowych w rolnictwie. Roczniki Naukowe Ekonomii Rolnictwa i Rozwoju Obszarów Wiejskich, No. 101(4), pp. 54-67.

Heady, C. (2007). Optymalne opodatkowanie jako wskazówka dla polityki podatkowej. In: M. Devereux (ed.), Efektywność polityki podatkowej (pp. 44). Warszawa: Wydawnictwo Sejmowe.

Kata, R. (2010). Korzystanie przez rolników i przedsiębiorców wiejskich z usług bankowych analiza preferencji i ograniczeń. Zagadnienia Ekonomiki Rolnej, No. 1(322), pp. 143-162.

Kisiel, R., Idźkowska, K. (2014). System opodatkowania rolnictwa w Polsce oraz w wybranych krajach Unii Europejskiej. Zeszyty Naukowe SGGW, Polityki Europejskie, Finanse $i$ Marketing, No. 12(61), pp. 64-78.

Kołodziejczak, M. (2016): Ocena korzystania z usług w gospodarstwach rolnych krajów Unii Europejskiej - analiza typologiczna. Zeszyty Naukowe SGGW w Warszawie - Problemy Rolnictwa Swiatowego, No. 16(3), pp. 192-198. 
Kołoszycz, E. (2017). Zmienność cen mleka a kształtowanie się nadwyżki na samofinansowanie inwestycji w gospodarstwach mlecznych. Zagadnienia Ekonomiki Rolnej, No. 2(351), pp. 77-93. DOI: $10.30858 /$ zer/83021.

Krzyżanowski, J. (2015). Wspólna polityka rolna Unii Europejskiej. Warszawa: CeDeWu.

Kubot, A., Czubak, W. (2016). Perspektywa wprowadzenia podatku dochodowego w rolnictwie w ocenia rolników. Journal of Agrobusiness and Rurar Development, 2(40), pp. 335-344. DOI: $10.17306 / J A R D .2016 .37$.

Kulawik, J., Lelong, P.Y., Pawłowska-Tyszko, J., Soliwoda, M. (2013). Systemy podatkowe w krajach Unii Europejskiej. Program Wieloletni 2011-2014, No. 83. Warszawa: IERiGŻ-PIB.

Kulawik, J., Ziółkowska, J. (2006). System finansowy rolnictwa a globalizacja finansowa. Program Wieloletni 2005-2009, No. 50. Warszawa: IERiGŻ-PIB.

Listokin, Y., Schizer, D. (2013). I Like To Pay Taxes: Taxpayer Support for Government Spending and the Efficiency of the Tax System. Tax Law Review, No. 66(2), pp. 179-215.

Nachtman, G., Cholewa,I.(2016). VAT w funkcjonowaniu gospodarstw rolnych w latach 2010-2013. Zagadnienia Ekonomiki Rolnej, No. 2(347), pp. 143-161. DOI: 10.5604/00441600.1203389.

Owsiak, S. (2002). Podstawy nauki finansów. Warszawa: PWE.

Pawlak, J., Paszko, D., Karwacki, G. (2017). Postawy rolników indywidualnych wobec wprowadzenia podatku dochodowego w rolnictwie. Roczniki Naukowe SERiA, Vol. XVII, Issue 4, pp. $225-230$.

Peciakowski, T., Gizicka, D. (2018). Rolnicy w obliczu wyzwań systemu podatkowego w Polsce perspektywa społeczna. In: P. Smoleń (ed.), Opodatkowanie rolnictwa w Polsce. Weryfikacja założen. Perspektywa zmian (pp. 1-22). Warszawa: C.H.Beck.

Pietrewicz, M. (1993). Polityka fiskalna. Warszawa: Poltext.

Podstawka, M. (1995). Opodatkowanie rolnictwa i perspektywy jego zmian w Polsce. Warszawa: Wydawnictwo SGGW.

Podstawka, M. (2000). System podatkowy w rolnictwie. Warszawa: Wydawnictwo SGGW.

Podstawka, M. (2005). Podstawy finansów. Warszawa: Wydawnictwo SGGW.

Presbitero, A., Sacchi, A., Zazarro, A. (2014). Property tax and fiscal discipline in OECD countries. Economic Letters, Vol. 124(3), pp. 428-433.

Seremak-Bulge, J. (ed.). (2005). Rozwój rynku mleczarskiego i zmiany jego funkcjonowania w latach 1990-2005. Program Wieloletni 2005-2009, No. 21. Warszawa: IERiGŻ-PIB.

Soliwoda, M., Pawłowska-Tyszko, J. (2014). Agricultural Taxation in Poland vs. Solutions in Selected EU Countries. Economic Science For Rural Development, No. 33, pp. 99-107.

Wasilewski, M., Ganc, M. (2012). Funkcjonowanie systemu podatkowego w rolnictwie oraz propozycje zmian w opinii rolników indywidualnych. Zeszyty Naukowe Uniwersytetu Szczecińskiego. Finanse, Rynki Finansowe, Ubezpieczenia, No. 689, pp. 725-733.

Winiarski, B. (2000). Uwarunkowania, cele i dziedziny polityki gospodarczej. In: B. Winiarski (ed.), Polityka gospodarcza (pp. 58-79). Warszawa: PWN.

Żyżyński, J. (2009). Budżet i polityka podatkowa. Wybrane zagadnienia. Warszawa: PWN. 


\title{
SYTUACJA EKONOMICZNA PRODUCENTÓW MLEKA ORAZ ICH OPINIE DOTYCZACEE OPODATKOWANIA TEJ DZIAŁALNOŚCI ROLNICZEJ
}

\begin{abstract}
Abstrakt
Od wielu lat poszukuje się w Polsce nowej konstrukcji opodatkowania dochodów z działalności rolniczej w miejsce podatku rolnego, który wciąż jest podstawowym obciażeniem polskich gospodarstw rolnych. W pracy przedstawiono wyniki analizy świadomości podatkowej wybranej grupy rolników, tj. prowadzacych produkcję mleka krowiego (32), aby na tej podstawie wyprowadzić wnioski dotyczace oceny fiskalizmu podatkowego wśród tej grupy zawodowej. Ciężary podatkowe, tak $w$ wymiarze całego systemu daninowego, jak $i$ nowych rozwiazań podatkowych są odczuwane $i$ wyrażane w sposób subiektywny. Ogólna ocena systemu podatkowego pod katem oczekiwań i reakcji społecznych zależy m.in. od poziomu wykształcenia podatników, świadomości prawnej, dominujacych postaw względem opodatkowania. Rezultaty zaprezentowanych badań ukazały niski stopień świadomości podatkowej badanych rolników. Podstawowym źródłem wiedzy o podatkach, w tym o ulgach podatkowych, sa inni rolnicy oraz informacje $z$ organów podatkowych. Fiskalny ciężar płaconych podatków dla badanej grupy rolników nie jest zbyt duży. Niewielu z nich uważa za co najmniej znaczne obciażenie fiskalne podatek rolny $(21,9 \%)$, podatek od nieruchomości $(21,9 \%)$ lub podatek leśny (3,1\%). Wedtug badanych powody niepłacenia podatków maja głównie ekonomiczny charakter. Respondenci uwazaja konstrukcje podatku rolnego za właściwa. Większość badanych (56,3\%) ma negatywny stosunek do wprowadzenia podatku dochodowego od rolników i ich działalności rolnej. Jeśli miałby być on wprowadzony, to powinny mu towarzyszyć ulgi podatkowe, związane gtównie z sytuacjami kryzysowymi, a także ulgi inwestycyjne i ulgi uzależnione od wielkości gospodarstwa. Pomimo modernizacji lub nabycia nowych gruntów właczonych do swoich gospodarstw, część gospodarzy nie skorzystała z ulgi inwestycyjnej. Przyczyna tego stanu rzeczy była m.in. nieznajomość odpowiednich przepisów prawnych. Rolnicy stabo znaja sposoby uiszczania zobowiazań podatkowych $i$ większości z nich nie korzystaja. Prawie wszyscy $(93,8 \%)$ rolnicy maja wiedze na temat możliwości odzyskania części pieniędzy wydanych na olej napędowy używany do produkcji rolnej na podstawie przedstawionych faktur. Nieliczni (6,3\%) uważaja, ze obecny limit zwrotu podatku akcyzowego jest zadowalający. Ponad 31\% badanych korzysta z fachowej pomocy (gtównie biura rachunkowego) w zakresie realizacji obowiązków zwiąanych z rozliczaniem VAT. Wybór sposobu rozliczania jest uwarunkowany ekonomicznie.
\end{abstract}

Słowa kluczowe: fiskalizm podatkowy, świadomość podatkowa, podatek rolny, producent mleka.

Accepted for print: 13.03.2020.

Unless stated otherwise all the materials on the website are available under the Creative Commons Attribution 4.0 International license.

Some rights reserved to the Institute of Agricultural and Food Economics - National Research Institute.

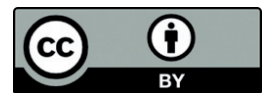

